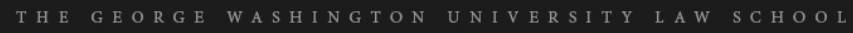

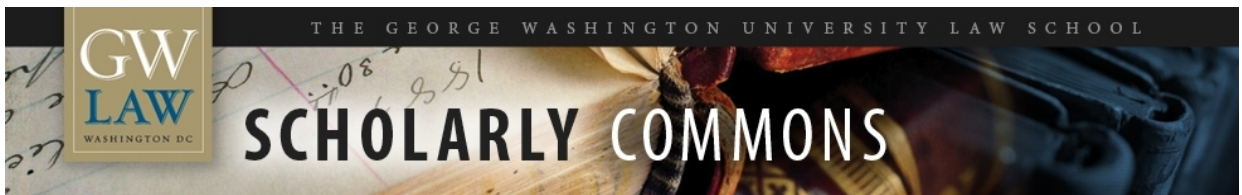

GW Law Faculty Publications \& Other Works

Faculty Scholarship

2014

\title{
Inconsistent Jury Verdicts
}

Stephen A. Saltzburg

George Washington University Law School, SSALTZ@law.gwu.edu

Follow this and additional works at: http://scholarship.law.gwu.edu/faculty_publications

Part of the Law Commons

\section{Recommended Citation}

Saltzburg, Stephen A., Inconsistent Jury Verdicts (2014). GWU Law School Public Law Research Paper No. 2014-62; 29 Crim. Just. (2014) ; GWU Law School Public Law Research Paper No. 2014-62; GWU Legal Studies Research Paper No. 2014-62. Available at SSRN: http://ssrn.com/abstract=2661014

This Article is brought to you for free and open access by the Faculty Scholarship at Scholarly Commons. It has been accepted for inclusion in GW Law Faculty Publications \& Other Works by an authorized administrator of Scholarly Commons. For more information, please contact spagel@law.gwu.edu. 


\section{Inconsistent Jury Verdicts}

\section{BY STEPHEN A. SALTZBURG}

Trint uries are supposed to render verdicts that are internally consistent. At times they do not. The law is clear that a defendant cannot set aside a conviction on the grounds that a verdict is inconsistent. (Dunn v. United States, 284 U.S. 390, 393 (1932) ("Consistency in the verdict is not necessary.").) But what if a trial judge explicitly instructs a jury that its verdict need not be consistent? The answer is provided in United States v. Moran-Toala, 726 F.3d 334 (2d Cir. 2013).

\section{The Facts}

The case began in 2005 when Immigration and Customs Enforcement (ICE) agents began investigating a Delta Airlines baggage handler's involvement with narcotics at New York's John F. Kennedy International Airport (JFK Airport). ICE agents obtained judicial authorization to wiretap Jorge Espinal's phone and discovered that the baggage handler was working with Henry Polanco, a narcotics distributor based in New York. Espinal told Polanco that, as a luggage-ramp supervisor at the airport, he could intercept packages containing narcotics on Delta planes and prevent them from being screened by Customs and Border Protection (CBP) agents. For his part, Polanco arranged for a Dominican Republic supplier to hide packages containing cocaine, heroin, and ecstasy on many Delta flights; six packages were eventually seized by CBP agents.

The drug smuggling was not without incident. On February 11, 2006, CBP agents seized a backpack with cocaine and heroin from a Delta flight from the Dominican Republic to New York. Not realizing that CBP agents had the backpack, Espinal informed Polanco that the backpack had ended up on the international baggage carousel and then was taken to unclaimed baggage. The Dominican supplier, meanwhile, suspected that Espinal and Polanco had stolen the drugs and demanded either the return of the drugs or payment for the loss. When Espinal learned that the backpack had been seized, he informed the Dominican supplier that his girlfriend worked for the government

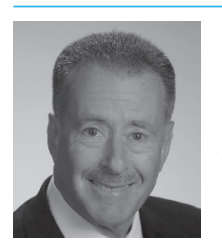

STEPHEN A. SALTZBURG is the Wallace and Beverley Woodbury University Professor at George Washington University School of Law in Washington, D.C. He is a past chair of the Criminal Justice Section and a regular columnist for Criminal Justice magazine. He is also author of the book, Trial Tactics, Third Edition (American Bar Association 2013), an updated and expanded compilation of his columns. and had access to confidential information that would prove that the seizure actually occurred.

The girlfriend-Elizabeth Moran-Toala-worked as a CBP officer from 2003 to 2007 at Hollywood International Airport in Fort Lauderdale, Florida. Her job required her to review flight manifests to identify airline passengers who were suspected of criminal activity. In that role, Moran-Toala had access to the Treasury Enforcement Communications System (TECS) database for work-related use. She was prohibited from browsing for personal or other non-work-related reasons. Three days after the backpack was seized in New York, she used the TECS database to access the seizure report.

In another incident, agents learned from the wiretap that Espinal and Polanco had arranged for a drug mule, Henry Cabrera, to carry a suitcase containing narcotics on an August 24, 2007, Delta flight from the Dominican Republic to JFK Airport. While waiting for Cabrera's plane to land so they could arrest him, agents saw Espinal attempt to enter a sterile area where they suspected he planned to collect the suitcase before Cabrera went through customs. However, those plans were foiled when Espinal was scared off by the heavy law enforcement presence. Espinal informed Polanco that he was unable to meet Cabrera and did not know what happened to the suitcase. This time it was Polanco who suspected that Espinal had stolen the drugs. Once again, Espinal said that he would contact his girlfriend to provide confirmation that police had, indeed, intervened. Five days later, Moran-Toala used the TECS database to access a record of Cabrera's arrest. Telephone records revealed that she called Espinal's airport work station the next day.

Three days after she accessed the TECS database to check on Cabrera, Moran-Toala used the database to determine whether another associate of Espinal's, Victor Perez, had any outstanding warrants. The search revealed none, and telephone records showed two outgoing calls from Moran-Toala's phone to Espinal.

The government charged Moran-Toala in the United States District Court for the Eastern District of New York with conspiracy to import more than one kilogram of heroin and more than five kilograms of cocaine (count one), and with conspiracy to use a government computer unlawfully (count two).

While awaiting trial on the New York charges, Moran-Toala pleaded guilty in the Southern District of Florida to involvement in a separate heroin importation and distribution conspiracy. That conspiracy included her sister and brother-in-law, who were officers of the CBP and Transportation Security Administration. Moran-Toala admitted that she used the TECS system to run travel checks for drug couriers flying out of Fort Lauderdale and to access a seizure report to prove to a supplier that a shipment was seized, not stolen. 


\section{The New York Trial Instructions}

In the New York case, Moran-Toala admitted to misusing her CBP computer, but claimed that she had no knowledge of the drug activity on the part of Espinal and Polanco. The trial judge in New York, after initially hesitating, decided to admit the signed, written plea allocution in the Florida case pursuant to Federal Rule of Evidence 404(b). The judge gave the following instruction to the jury:

If you determine, in respect to count two, that the defendant is guilty of that count, you must determine whether the government has proved beyond a reasonable doubt ... that the offense in [18 U.S.C. $\S 1030(a)(2)(B)(i i)]$ was committed in furtherance of a criminal act in violation of the Constitution and laws of the United States; namely, the conspiracy to import narcotics as charged in count one. It's linked to count one if you find she is guilty.

The phrase in furtherance means with the intent to help, advance, move forward, promote or facilitate. The government must therefore show that the defendant engaged in the conduct of accessing the United States Department of Homeland Security computer in excess of authorization, with the intent to advance, move forward, promote or facilitate the conspiracy charged in count [one] about which I've already instructed you.

(Moran-Toala, 726 F.3d at 339-40 (first alteration omitted).)

The trial judge also provided the jury with a verdict sheet containing four "questions":

1. Verdict on count one.

2. Amount of heroin and cocaine involved in the conspiracy, if any.

3. Verdict on count two.

4. "Was the [unlawful computer use] conspiracy in furtherance of the crime charged in Count One, namely, the conspiracy to import a controlled substance?" (Id. at 340.)

\section{Jury Questions}

During the first day of deliberations, the jury sent the judge a note that asked, "Count 2: must the verdict in \#4 be in agreement with Count \#1?" (Id.) The jury was asking whether the findings it would use to answer question 4 had to be consistent with its verdict on count one. The trial judge consulted with counsel. The prosecution urged a "no" answer, arguing that Moran-Toala could have intended to have exceeded her computer authority in furtherance of the narcotics conspiracy without having enough knowledge to be a member of the conspiracy. Defense counsel urged a "yes" answer to foreclose the possibility of inconsistent verdicts. The trial judge's initial reaction was that the defense was correct, but ultimately he told the jury that its verdict on count one and the felony enhancement did not have to be "in agreement." The jury returned its verdict about 20 minutes after getting the judge's response to its note. It acquitted MoranToala of the narcotics conspiracy, but convicted her of conspiring to unlawfully access a computer in furtherance of the same narcotics conspiracy.

\section{Post-Trial Motion}

Moran-Toala filed a post-trial motion pursuant to Federal Rule of Criminal Procedure 33 to set aside the jury's enhancement finding. The trial judge concluded that the jury's verdict was inconsistent.

While there may be scenarios in which an individual can act in furtherance of a conspiracy without joining the conspiracy, there is no view of the evidence in this particular case that would permit that conclusion. The government's theory at trial was that Moran-Toala would, at a co-conspirator's request, periodically access confidential information regarding narcotics seizures and other information and pass it on to the coconspirator. ... By finding that Moran-Toala committed the conspiracy computer offense "in furtherance of the crime charged in Count one," the jury necessarily determined that she had agreed with another-her co-conspirator on the computer charge - to commit the crime; that she had intentionally advanced the narcotics conspiracy; and that she had committed an overt act in furtherance of the conspiracy. Put simply, Moran-Toala could not have intentionally misused her computer to advance a narcotics conspiracy without being a member of that conspiracy. Thus, when the jury asked whether the special verdict on the [felony] enhancement needed to be "in agreement" with its verdict on count one, it was effectively asking whether the verdict had to be consistent.

(Moran-Toala, 726 F.3d at 340-41.)

But the judge also concluded that even if the court's error produced the inconsistency, MoranToala was not entitled to relief.

\section{The Appeal}

The court of appeals first noted that because the jury acquitted the defendant on count one, the double jeopardy clause barred any retrial of the 
defendant on that count, regardless of the correctness of the verdict or whether it was a consistent verdict. The court cited not only Dunn but also its decision in United States v. Acosta, 17 F.3d 538 (2d Cir. 1994), for the proposition that inconsistent verdicts are unreviewable on appeal. But the court noted that Moran-Toala was challenging the judge's "no" instruction to the jury in response to its question rather than simply focusing on inconsistency.

The court observed that the judge initially and correctly explained to the jury that its verdict on the narcotics conspiracy should be "linked" to its findings on the felony enhancement because the felony enhancement only applied if Moran-Toala unlawfully used her CBP computer with the intent to further the conspiracy. The court opined that the jury clearly recognized the tension between acquittal on count one and an affirmative answer to question 4 and that the trial judge essentially blessed the jury's desire to be inconsistent.

The court concluded that, had the judge answered "yes" to the jury's question and had the jury nonetheless returned an inconsistent verdict, the jury's act would have been one of nullification; but the judge's "no" answer to the jury effectively invited the jury to nullify the law and misled the jury as to its duty.

\section{Nature of the Error}

The court ultimately concluded that the judge's erroneous "no" answer to the jury did not amount to "structural error," which always requires reversal. Citing Hedgpeth v. Pulido, 555 U.S. 57 (2008), the court reasoned that a harmless error analysis applies to instructional errors unless an error categorically vitiates all the jury's findings, and concluded that the erroneous "no" should be subject to harmless error review. The court explained the difficulty in assessing the effect of the error:

Harmless error review in this case is complicated by the factual, if not legal, inconsistency in the jury's verdicts. The very reason such verdicts are unreviewable in and of themselves is because we could do no more than "try to guess which of the inconsistent verdicts is the one the jury really meant." We might speculate as to what the jury actually had in mind in order to seek to reconcile the two verdicts: perhaps the jury found that Moran-Toala had insufficient knowledge of the narcotics conspiracy to support a conviction on Count One, in which case a properly instructed jury likely would have also rejected the felony enhancement. Or the jury might have found that Moran-Toala's intent to further the narcotics conspiracy by misusing her CBP computer also proved her membership in the narcotics conspiracy, but it did not wish to convict on such a serious charge without evidence that she personally imported or sold drugs; in that case, a properly instructed jury likely would have applied the felony enhancement. The problem with either speculation, though, beyond the fact that they are speculations, is that they do not account for the jury's query: "Count 2: must the verdict in $\# 4$ be in agreement with Count \#1?" This note strongly suggests that the jury itself could not reconcile the verdicts on the two counts and was seeking (and obtained) permission to render its contemplated verdicts despite the inconsistency.

There is thus no serious doubt that the erroneous instruction contributed to any inconsistency in the verdicts inasmuch as it explicitly permitted them. We are not unaware of the fact that the district court's instruction ultimately resulted in a highly favorable verdict for Moran-Toala, who was convicted of the less serious charge and acquitted of the more serious one. But, in light of the dearth of evidence of Moran-Toala's knowledge of the Espinal-Polanco airport conspiracy, it is nevertheless possible that a jury would have acquitted her of the narcotics conspiracy and declined to apply the felony enhancement had the supplemental instruction been correct and informed the jury that inconsistent verdicts are impermissible. We therefore cannot say with any confidence that it is clear beyond a reasonable doubt that a properly instructed jury would have convicted Moran-Toala of felony-level unlawful computer access conspiracy. Accordingly, the conviction on Count Two must be vacated and the case remanded to the district court for retrial, should the government be inclined to pursue the charge.

(Moran-Toala, 726 F.3d at 344-45 (footnote omitted) (citation omitted).)

\section{The Lesson}

The lesson of the case is clear. Whether courts and judges like it or not, juries have the ability to engage in a type of jury nullification by returning inconsistent verdicts. The law is well established that courts will not review such verdicts and set aside convictions because a jury compromised. But courts will not knowingly encourage nullification, and if they do the encouragement is reviewable and may, as in Moran-Toala, result in the setting aside of a conviction when it is too difficult to ascertain what the jury would have done absent the improper judicial encouragement. 